\title{
Molecular characterization of avian reovirus isolates in Tunisia
}

\author{
Ymene Hellal Kort ${ }^{1}$, Hager Bourogâa', Latifa Gribaa', Daniel Scott-Algara² and Abdeljelil Ghram
}

\begin{abstract}
Background: Genotype analyses of avian reoviruses isolated from organ samples collected from chickens with suspicious clinical symptoms, between 1997-2008, was based on sequences for both $\sigma C$ and $\sigma B$ genes and aligned with those published in the Genbank, making it possible to carry out studies of molecular classification and relationships.

Methods: The full length of the known variable protein $\sigma C$ and part of the $\sigma B$ encoding genes, were amplified with RT-PCR, using conserved primers. PCR products were sequenced and the sequences were analyzed and aligned with avian reovirus sequences from the Genbank database.

Results: The sequences of $\sigma C$-encoding genes of all the isolated strains indicated their close relationship with the American, Chinese and Indian strains. Taking the American strain $\$ 1133$ as a reference, the two Tunisian isolates 97.1 and 97.2 showed some nucleotide substitutions. For isolate 97.1 , the substitution was silent whereas for strain 97.2 the mutation was at the first position of the corresponding codon and induced the substitution of the amino acid encoded. For the $\sigma B$-encoding gene, the sequences of the Tunisian strains showed mutations at positions two or three of the corresponding codons, inducing substitutions of amino acids at these positions. The phylogenic trees based on $\sigma C$ and $\sigma B$ encoding genes indicated closer relationship between Tunisian, American and Taiwanese isolates of genotype $\mathrm{I}$.

Conclusion: Our study describes the genotype of avian reoviruses that are not yet well characterized genetically. The characterization and classification of these viruses might be significant for understanding the epidemiology of malabsorption syndrome and viral arthritis, and improving our knowledge of the genotype of strains circulating in Tunisian flocks. Furthermore, the study of their variable pathogenicity could be extremely important in the choice of the appropriate vaccine strain to control disease.
\end{abstract}

Keywords: Avian reoviruses, Malabsorption syndrome, Arthritis, $\sigma \mathrm{C}$ gene, $\sigma B$ gene, Genotyping

\section{Background}

Avian reovirus (ARV) pathogens are found worldwide [1-3] and their molecular characterization, using PCR and nucleotide sequence analysis, have been described [4-6]. Yet, only a limited number of genomic sequences belonging mainly to the $\mathrm{S}$ - class, has been published. These sequences have characterized strains isolated from USA, Taiwan, Germany, Netherlands, Australia, Japan and China $[7,8]$. Recently, $\sigma \mathrm{C}$ protein sequences of some Indian strains were submitted to the Genbank.

\footnotetext{
*Correspondence: abdeljelil.ghram@pasteur.rns.tn

'Laboratory of Epidemiology and Veterinary Microbiology, Institut Pasteur de Tunis, University of Tunis - El Manar, 13 place Pasteur, BP 74, 1002,

Tunis-Belvedere, Tunisia

Full list of author information is available at the end of the article
}

Particles of ARV present two layers of capsid and 10 segments of double-stranded RNA [9]. Genomic segments can be separated on polyacrylamide gel electrophoresis into three different classes, based on size, named L (large), $\mathrm{M}$ (medium) and $\mathrm{S}$ (small). They encode for at least 8 structural and four non-structural proteins [10,11]. Amongst the S-class segments of ARV, the segment S1 contains three open reading frames that are translated into $\mathrm{P} 10, \mathrm{P} 17$ and $\sigma \mathrm{C}$ proteins $[10,11]$. The protein P10 induces cell-cell fusion $[12,13]$ while P17 causes cellular protein translation shutoff and cell cycle arrest $[14,15]$. The $\sigma \mathrm{C}$ protein plays a role for virus attachment [16] and as apoptosis inducer [17]. It has been demonstrated that cell entry of avian reovirus follows a caveolin-1-mediated and
C Bïomed Central

(c) 2013 Hellal Kort et al.; licensee BioMed Central Ltd. This is an Open Access article distributed under the terms of the Creative Commons Attribution License (http://creativecommons.org/licenses/by/2.0), which permits unrestricted use, distribution, and reproduction in any medium, provided the original work is properly cited. 
dynamin-2-dependent endocytic pathways that require activation of p38 MAPK and Src signaling pathways [18]. It has also been suggested that it represents the target for type-specific neutralizing antibodies. The $\sigma \mathrm{B}$ protein, encoded by the S3 gene [10,19], carries group-specific neutralizing epitopes [20]. Recently, the ARV $\sigma$ A protein, encoded by the $S 2$ gene [16], has been identified as a double-stranded RNA binding protein that may be involved in interferon resistance [21]. Another viral protein, oNS encoded by the S4 gene, has been reported as having a single-stranded RNA binding activity [22,23].

This paper reports the analyses of the $\sigma \mathrm{C}$ and part of the $\sigma B$ encoding genes along with the nucleotide sequences of 15 ARV isolates, identified over a 12 -year period. To the best of our knowledge, this is the first report regarding the genotypic classification of ARV in Tunisia and in Africa. Because ARV are important poultry pathogens, causing arthritis, chronic respiratory disease and malabsorption syndrome, which result in considerable economic losses to the poultry industry $[24,25]$, better understanding their pathogenicity is economically important.

\section{Methods}

Being the major laboratory doing diagnostic and research for poultry diseases in Tunisia, samples from different flocks and regions were sent to the laboratory, by private and governmental veterinarians, for the diagnostic of major avian diseases. Fifteen ARV isolates were identified from chickens with viral arthritis, malabsorption syndrome or other suspected symptoms. The flocks were located in governments in the north (Bizerte, Ben Arous and Nabeul), the center (Sousse, Monastir and Mahdia) and the south (Sfax) of the country. ARV were propagated in specific pathogen-free (SPF) embryonnated chicken eggs, followed in cultures of primary chicken embryo fibroblast (CEF) or liver (CEL) cells [7]. The virus was detected when strong cytopathic effects (CPE) were observed after 3 to 5 subcultures; virus stocks were subsequently prepared in $75 \mathrm{~cm} 2$ flasks. Once $70-80 \%$ CPE were developed, cell cultures were frozen and thawed 3 times, then clarified with low centrifugation at $3000 \mathrm{rpm}$ for $20 \mathrm{~min}$. Supernatants were then conserved in aliquots at $-80^{\circ} \mathrm{C}$ for later use. The vaccine strain (Nobilis S1133) was propagated in CEF cells and treated as described above. Viral RNA was extracted from supernatants using Trizol (Gibco Brl) as per the procedural modification described by Lee et al. [26]. Briefly, $1 \mathrm{ml}$ of Trizol was incubated with $300 \mu \mathrm{l}$ of clarified supernatant for $5 \mathrm{~min}$, at room temperature. RNA was then isolated with chloroform (Sigma-Aldrich, France) and precipitated with isopropan-alcohol (SigmaAldrich, France) overnight. Total RNA was used as a template for RT-PCR reactions; non infected-cells and Rnase free water were used as negative controls.

\section{Primers}

Primers used for RT-PCR reactions (Table 1) were selected according to the sequences of S1 and S3 segments from available ARV sequences $[4,19,27]$.

\section{Reverse transcription (RT), PCR and double Nested PCR (N-PCR)}

A double N-PCR amplified the full length of the $\sigma \mathrm{C}$ encoding gene. For the RT reactions, RNA was denatured in the presence of S1C or S1G forward primers (50pmol) and $1 \mu \mathrm{l}$ RNasin (Promega) in a total volume of $11 \mu \mathrm{l}$, for $10 \mathrm{~min}$, and rapidly cooled on ice. Subsequently, $9 \mu \mathrm{l}$ RT mixture, containing $4 \mu \mathrm{l}$ X first strand buffer (Invitrogen), $2 \mu \mathrm{l}$ DTT and $2 \mu \mathrm{dNTP}(10 \mathrm{mM})$ ) were added to each sample. After $2 \mathrm{~min}$ incubation at $42^{\circ} \mathrm{C}$, $1 \mu \mathrm{l}$ superscript reverse transcriptase (Invitrogen) was added to each tube. The RT was carried out at $42^{\circ} \mathrm{C}$ for $50 \mathrm{~min}$. The cDNA amplification was performed in $10 \mu \mathrm{l}$ volume, containing 1,5 mM MgCl $2,1 X$ PCR buffer (Invitrogen), 2,5U Taq DNA Polymerase (Invitrogen), 0,5 $\mu \mathrm{M}$ of each primer (S1C and S1D, S1G and S1H) and $5 \mu \mathrm{l}$ of sample from the RT reaction. PCR reactions were subjected to 35 cycles (denaturation for $1 \mathrm{~min}$ at $94^{\circ} \mathrm{C}$, annealing for $1 \mathrm{~min}$ at $55^{\circ} \mathrm{C}$, extension for $2 \mathrm{~min}$ at $70^{\circ} \mathrm{C}$ ) and one final extension cycle at $70^{\circ} \mathrm{C}$ for $10 \mathrm{~min}$ for the amplification of the whole $\sigma \mathrm{C}$ gene. For the $\mathrm{N}$ PCR, $5 \mu \mathrm{l}$ of $1 / 10$ or $1 / 100$ of each RT-PCR product was amplified using primer sets (S1E and S1F, S1I and S1H) with the same components as for the PCR reaction. Samples were subjected to 35 cycles (45s denaturation at $94^{\circ} \mathrm{C}$, $1 \mathrm{~min}$ annealing at $55^{\circ} \mathrm{C}$ and $1 \mathrm{~min}$ extension at $70^{\circ} \mathrm{C}$ ) with a one final extension at $70^{\circ} \mathrm{C}$ for $7 \mathrm{~min}$.

For the $\sigma \mathrm{B}$ gene, samples were treated as described above. RT was performed using P1 primer and samples were subjects to 35 cycles (denaturation for $5 \mathrm{~min}$ at $94^{\circ} \mathrm{C}$, annealing for $30 \mathrm{~s}$ at $50^{\circ} \mathrm{C}$ and extension for $70 \mathrm{~s}$ at $70^{\circ} \mathrm{C}$ ) with a one final extension for $7 \mathrm{~min}$ at $70^{\circ} \mathrm{C}$.

\section{Analysis of amplified products}

After completion of the PCR reactions, $10 \mu \mathrm{l}$ of reaction mixtures were loaded onto a $2 \%$ agarose gel for 1 hour in TAE buffer (90 mM Tris- $\mathrm{HCl}, 90 \mathrm{mM}$ acetic acid, $2 \mathrm{mM}$ EDTA, pH 8,3), containing $5 \mu \mathrm{l} / \mathrm{ml}$ ethidium bromide, for electrophoresis and subsequent visualization with ultraviolet transilluminator. A DNA ladder of $100 \mathrm{bp}$ was run as a size marker.

\section{Sequencing analysis}

PCR products were used for direct sequencing using forward and reverse primers to obtain the full length of $\sigma \mathrm{C}$ and part of $\sigma B$ encoding genes. Sequencing was done three times using PCR products of the same isolate to avoid cross contamination. The ABI Prism Big Dye Terminator Cycle Sequencing Reaction kit (Applied 
Table 1 RT-PCR primer sequences and expected PCR products

\begin{tabular}{|c|c|c|c|c|}
\hline Designation & Sequence $\left(5^{\prime}-3^{\prime}\right)$ & Gene & Location $^{a}$ & PCR products (bp) \\
\hline $\mathrm{SIC}$ & ATTGAATTCTCTCTGTTATCTAACCTTG & $\sigma C$ & $446-472$ & 738 \\
\hline S1D & AAGGAATTCGTTGAGAACAGAAGTAGG & $\sigma C$ & $1183-1157$ & \\
\hline S1E & TCTGAATTCATCCGCAGCGAAGAGAGGTG & $\sigma C$ & $630-658$ & 342 \\
\hline $\mathrm{S} 1 \mathrm{~F}$ & AGTGAATTCAGTATCGCCGTGCGCAG & $\sigma B$ & $971-943$ & \\
\hline S1G & CCTGAATTCGTGACTGACTTAACGAAC & & 910-936 & 720 \\
\hline S11 & ACGAATTCTITCATTAGACATGGACC & & $1130-1156$ & 520 \\
\hline $\mathrm{S} 1 \mathrm{H}$ & TAAGAATTCCCAGTACGGCGCCACA & & $1629-1603$ & \\
\hline P1 & TAACATCTAGCTATTTG & & $67-83$ & 627 \\
\hline P2 & CAAGCATTACAGGGCCAGC & & $720-738$ & \\
\hline
\end{tabular}

${ }^{a}$ Location according to Yin et al.[19] and Liu et al. $[27,28]$.

Biosystems, Foster City, CA) was used and electrophoreses were run on polyacrylamide gel POP 7 in a four-capillary Applied Biosystem Genetic Analyser. Nucleotide sequences were aligned for comparison using "Clustal W" from BioEdit Sequence Alignment Editor [29,30]. The sequences were deposited in the Genbank database (see Table 2 for the accession numbers of the nucleotide sequences).

\section{Phylogenic analysis}

The full length of the $\sigma \mathrm{C}$ and only part of the $\sigma \mathrm{B}$ gene sequences were translated using the Bio-Edit program. The phylogenetic tree, for either epidemiological or phylogenic relationship studies, was constructed using Splits Tree version 4.10 Software with the NeighbourJoining (NJ) method and bootstrap analysis $(\mathrm{n}=1000)$, to determine the best fitting tree for each gene [34].

\section{Results}

Fifteen Tunisian ARV were isolated (Table 2) in SPF eggs, CEF and/or CEL cell cultures. S1133 vaccine strain, used as a control, was propagated in CEF cultures. Aliquots of clarified freeze-thawed cell supernatants ( 4 or 5 passages) were used for RNA extraction. Using primer pairs of S1CS1D, S1E-S1F, S1G-S1H, S1I-S1H for the $\sigma \mathrm{C}$ gene and P1-P2 for the $\sigma B$ gene, RNA extracts from all ARV isolates as well as the S1133 strain was transcribed into cDNA and amplified, producing fragments with expected sizes of 738 , 342, 720, 500 and $672 \mathrm{bp}$, respectively. PCR products from S1133 strain and the Tunisian isolates were obtained, indicating that primer regions were conserved in our strains. RNA extracted from non-infected cells and Rnase-free water were used as negative controls and no DNA amplification was observed, indicating that the amplified viral DNA was specific and did not originate from contamination.

\section{Sequence analyses and phylogenic study}

To gather information about the genetic classification of the Tunisian isolates, different sequences of $\sigma \mathrm{C}$ and $\sigma \mathrm{B}$ encoded genes, from pathogenic and vaccine strains were analysed. ARV sequences are labelled as submitted by our laboratory or by others (Table 2) $[4,7,27,28,31-33]$.

Alignment of nucleotides of the $\sigma \mathrm{C}$ encoded gene of all identified strains showed a close relationship with the American S1133 and the English JR1 pathogenic strains [33] (Table 2). Analyses of the nucleotide sequences revealed that the Tunisian strains showed the same sequences as the strain S1133, except for the 97.1 and 97.2 isolates. The first one showed a substitution of Guanine with Adenine at the position 354. This mutation was observed for all Chinese, Japanese and Indian strains (pathogenic and vaccine ones) and the only isolate from Canada. However, six of all American (2048, 1733, 138, 176, GA41560, MS42563-1), seven of all Taiwanese (T6, 70505, 919, 601G, 601SI, R2/TW, 916) and one of two Australian (SOM-4) pathogenic strains showed the same mutation. Moreover, the 97.1 had the same sequence as the only English pathogenic strain JR1, except that the later shows a substitution of Guanine with Thymine at the position 927. Multi-alignment of deduced amino acid (AA) sequences revealed that the mutations at positions 354 and 927 were synonyms; thus no differences were found in the AA sequences between 97.1, S1133 and JR1 strains (Figure 1a). For the second strain 97.2, a substitution of Adenine with Guanine at position 355 of the $\sigma \mathrm{C}$ gene was observed. This mutation was at the first position of the corresponding codon and induced the substitution of the amino acid encoded (Figure 1a). Same mutation was likewise detected for the German strain GEL13a98M and the two American strains MS42563-1 and 42563-4. Nevertheless, at this position, three of German (GEL0597M, GEL0397T, GEL0196T) and Dutch (NLA1396, NLI098M, NLI196) strains and two Taiwanese strains $(918,1017-1)$ showed one Cytosine. The two American strains GA40963 and GA41565, however, showed one Thymine at this position.

Using S1133 as a reference strain, alignment of nucleotide sequences of the $\sigma B$ encoded gene, showed 
Table 2 Virus used in this study and sequences submitted to Genbank by us and others

\begin{tabular}{|c|c|c|c|c|c|}
\hline \multirow[t]{2}{*}{ Isolate } & \multirow[t]{2}{*}{ Symptoms ${ }^{a}$} & \multirow[t]{2}{*}{ Origin } & \multirow[t]{2}{*}{ Year $^{b}$} & \multicolumn{2}{|c|}{$\begin{array}{l}\text { Genbank accession } \\
\text { number }\end{array}$} \\
\hline & & & & $\overline{\sigma C}$ & $\sigma B$ \\
\hline$S 1133$ & $V \cdot A^{c}$ & USA & 1973 & AF330703 & U20642 \\
\hline 2408 & Mal.S. ${ }^{d}$ & USA & 1983 & AF204945 & AF208038 \\
\hline 1733 & Mal.S. & USA & 1983 & AF004857 & AF004856 \\
\hline 138 & V.A. & USA & $U N^{f}$ & AF218359 & AF059721 \\
\hline 176 & V.A. & USA & UN & AF218358 & AF059720 \\
\hline $42563-4$ & R.S.S & USA & 2005 & DQ872801.1 & N.A. \\
\hline GA41565 & R.S.S. & USA & 2005 & DQ872799.1 & N.A. \\
\hline GA41560 & R.S.S. & USA & 2005 & DQ872798.1 & N.A. \\
\hline GA 40973 & RS..S & USA & 2005 & DQ872797.1 & N.A. \\
\hline MS46523-1 & R.S.S. & USA & 2005 & ABJ09661.1 & N.A. \\
\hline GA40963 & R.S.S. & USA & 2005 & ABJ09657.1 & N.A. \\
\hline V.A.Vac & Vaccine $^{g}$ & USA & 2006 & EF122837 & N.A. \\
\hline AVS-B & R.S.S. & USA & 2005 & YP004226527 & YP004226529 \\
\hline$J \mathrm{R} 1$ & $N \cdot A^{h}$ & England & UN & EF122836.1 & N.A. \\
\hline TU399 & V.A. & Tunisia & 1998 & HM751135 & HM751120 \\
\hline TU430 & V.A. & Tunisia & 1998 & HM751137 & HM751122 \\
\hline TU429 & Mal.S. & Tunisia & 1998 & HM751136 & HM751121 \\
\hline TU435 & V.A. & Tunisia & 1998 & HM751138 & HM751123 \\
\hline TU96 & V.A. & Tunisia & 1999 & HM751139 & HM751124 \\
\hline TU97.1 & V.A. & Tunisia & 1999 & HM751140 & HM751125 \\
\hline TU97.2 & V.A & Tunisia & 1999 & HM751141 & HM751126 \\
\hline TU119 & Unclear $^{i}$ & Tunisia & 1999 & HM751142 & HM751127 \\
\hline TU420 & Unclear & Tunisia & 2000 & HM751143 & HM751128 \\
\hline TU87 & Unclear & Tunisia & 2001 & HM751144 & HM751129 \\
\hline TU5 & Mal.S. & Tunisia & 2002 & HM751145 & HM751130 \\
\hline TU71B1 & Unclear & Tunisia & 2002 & HM751146 & HM751131 \\
\hline TU105B6 & Mal.S. & Tunisia & 2002 & HM751147 & HM751132 \\
\hline TU360 & Mal.S. & Tunisia & 2004 & HM751148 & HM751133 \\
\hline TU1390 & Mal.S. & Tunisia & 2008 & HM751149 & HM751134 \\
\hline NLI1296M & Mal.S & Netherlands & 1996 & AF354230.1 & N.A. \\
\hline NLI0298M & Mal.S & Netherlands & 1998 & AF354229.1 & N.A. \\
\hline NLA1396T & V.A. & Netherlands & 1996 & AF354228.1 & N.A. \\
\hline $99 \mathrm{G}$ & Unclear & China & 1999 & N.A. & DQ415659 \\
\hline T-98 & V.A. & China & 2006 & ABK51295.1 & ABK32526.1 \\
\hline C-98 & V.A. & China & 2006 & ABK51292.1 & ABK32523.1 \\
\hline G-98 & V.A. & China & 2006 & ABG43119.1 & ABK32524.1 \\
\hline HB06 & V.A. & China & 2008 & ACB11346.1 & N.A. \\
\hline OS161 & Mal.S. & Japan & 1970 & AF204946 & AF301471 \\
\hline Fahey and Crawley & R.D. ${ }^{k}$ & Canada & 1954 & ABI97289.1 & N.A. \\
\hline GEL13a98M & Mal.S & Germany & 1998 & AF354226.1 & N.A. \\
\hline GEL13b98M & Mal.S & Germany & 1998 & AF354227.1 & N.A. \\
\hline GEL12 98M & Mal.S & Germany & 1998 & AF354225.1 & N.A. \\
\hline
\end{tabular}


Table 2 Virus used in this study and sequences submitted to Genbank by us and others (Continued)

\begin{tabular}{|c|c|c|c|c|c|}
\hline GEL06 97M & Mal.S & Germany & 1997 & AF354224.1 & N.A. \\
\hline GEL05 97M & Mal.S & Germany & 1997 & AF354223.1 & N.A. \\
\hline GEL03 97T & V.A. & Germany & 1997 & AF354222.1 & N.A. \\
\hline GEL01 96T & V.A. & Germany & 1997 & AF354221.1 & N.A. \\
\hline GEI09 97M & Mal.S & Germany & 1997 & AF354220.1 & N.A. \\
\hline GEl1097M & Mal.S & Germany & 1997 & AF354219.1 & N.A. \\
\hline K5 & N.A. & India & 2008 & EU681261.1 & N.A. \\
\hline 820 & N.A. & India & 2008 & EU681260.1 & N.A. \\
\hline MKA & N.A. & India & 2008 & EU681259.1 & N.A. \\
\hline MS-4 & N.A. & India & 2008 & EU681258.1 & N.A. \\
\hline 1884 & N.A. & India & 2008 & EU681257.1 & N.A. \\
\hline $6-10$ & N.A & India & 2008 & EU681256.1 & N.A. \\
\hline VA-1 is & V.A & India & 1983 & EU681254 & N.A \\
\hline VA-1 & Vaccine & India & 2008 & EU681255.1 & N.A. \\
\hline Bareilly son-1 & N.A. & India & 2008 & HM015906.1 & N.A. \\
\hline Bareilly & N.A. & India & 2008 & FJ949087.1 & N.A. \\
\hline T6 & R.D & Taiwan & 1970 & AF204948 & AF208036 \\
\hline 750505 & V.A. & Taiwan & 1986 & AF204950 & AF208035 \\
\hline 919 & Normal & Taiwan & 1992 & AF204949 & AF208034 \\
\hline $601 G$ & V.A. & Taiwan & 1992 & AF297217 & AY008384 \\
\hline $601 \mathrm{SI}$ & VA. & Taiwan & 1992 & AF204947 & AF208037 \\
\hline $\mathrm{R} 2 / \mathrm{TW}$ & V.A. & Taiwan & 1992 & AF297213 & AF301472 \\
\hline 918 & Mal.S. & Taiwan & 1992 & AF297215 & AF301473 \\
\hline 916 & Mal.S. & Taiwan & 1992 & AF297214 & AY008383 \\
\hline $1017-1$ & Mal.S. & Taiwan & 1992 & AF297216 & AF301474 \\
\hline
\end{tabular}

${ }^{a}$ : Symptoms observed in infected chickens; ${ }^{b}$ : year of isolation of the corresponding strain; ${ }^{c}$ : viral arthritis; ${ }^{d}$ : malabsorption syndrome; ${ }^{e}$ : Runting-stunning syndrome; ${ }^{\mathrm{f}}$ : year of isolation not known; ${ }^{\text {: }}$ : sequences of vaccines derived from pathogenic strains S1133 or VA-1 is; ${ }^{\text {h}}:$ data not available; ${ }^{i}:$ chicken's symptoms not described; ': apparent healthy chickens; ${ }^{\text {: }}$ : Respiratory disease; ': Accession Numbers submitted by us or according to Shapouri et al. [4]; Kant et al. [7]; Shmulevitz et al. [31]; Liu et al. [27,28]; Zhang et al. [32]; Guo et al. [33].

some substitutions. The first one, located at the position 308, was observed only for TU430 and TU360 isolates. The second substitution located at position 438, was observed for strains TU429 and TU430 which were isolated in 1998, for TU96 and TU119, isolated in 1999 and for TU360, collected in 2004. Lastly, three substitutions were observed at positions 467, 521 and 656 for all Tunisian strains. Multi-alignment of these strains with the most published ones indicated that the sequences of their $\sigma \mathrm{B}$ encoded gene are closely related to the Chinese 99G strain, which shows the same nucleotide sequence as the three isolates (TU429, TU96, TU119). Deduced AA sequences demonstrated that all the observed mutations are non-synonymous and imply substitutions of the corresponding AA (Figure 1b).

Phylogenic comparison of genotype clustering based on nucleotide sequences of the $\sigma \mathrm{C}$ gene of the Tunisian isolates with published one, showed that they are closely related to each other and can be classified in cluster I with all Indian and Chinese strains as well as those isolated from England, Japan and Canada. They remain different from Australian and Dutch isolates, found only in the clusters V and VI, respectively. The Taiwanese isolates are more dispersed and evolved in at least 4 clusters. The isolates from Germany and America are the most dispersed ones and grouped in 5 different clusters and only one American strain 138 is placed in cluster II (Table 2, Figure 2a) [7,8,27].

For the $\sigma \mathrm{B}$ gene sequences, the phylogenic tree showed that the Tunisian strains are relatively closer to each other and can be classified in the same cluster I with the only Japanese strain OS161, all Chinese and four Taiwanese strains. The remainder Taiwanese strains are classified in cluster II and III, respectively. However, the American strains are dispersed in clusters I and III (Table 2, Figure 2b). 

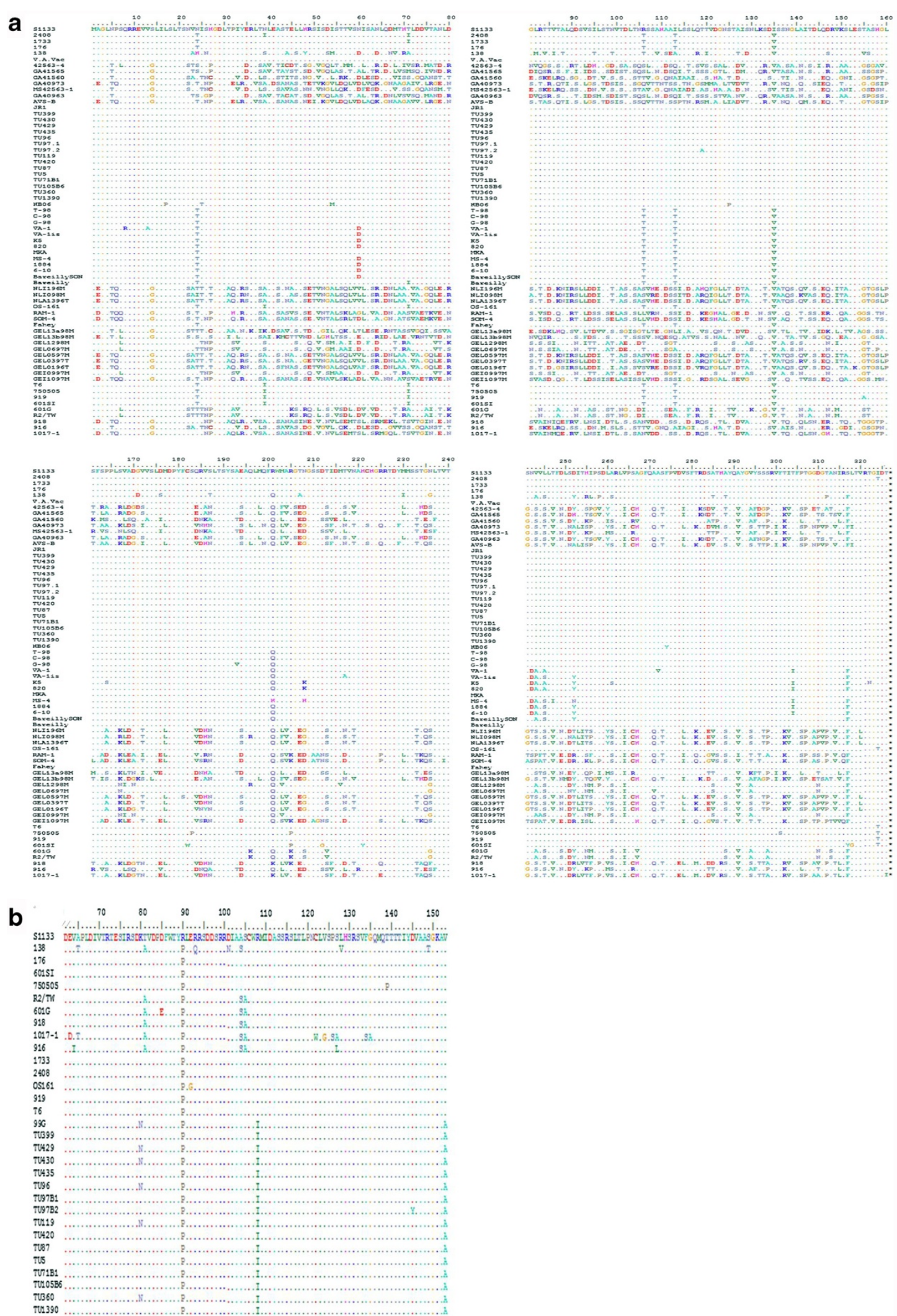

Figure 1 (See legend on next page.) 
(See figure on previous page.)

Figure 1 Multiple sequence alignment of $\sigma \mathrm{C}$ (326 AA) (a) and part of $\sigma B$ proteins (b) (residue 67 to 153) of ARV. The predicted AA sequences of $\sigma C$ and part of $\sigma B$ proteins of 15 Tunisian ARV isolates (TU339, TU429, TU430, TU435, TU96, TU97.1, TU97.2, TU119, TU420, TU87, TU5, TU71B1, TU105B6, TU360 and TU1390) were aligned and compared to previously published sequences using 'Clustal W' from Bio-Edit Sequence Alignment Editor [27,29]. Sequencing was done three times using PCR products of the same isolate to avoid cross contamination. AAs are numbered up the sequences residues. AAs identical to the S1133 pathogenic strain sequence are indicated by dot. Genbank accession numbers of the strains, either determined in this study or submitted by others, are cited in Table 2.

\section{Discussion}

ARV pathogenicity is very heterogeneous and ARV strains are associated with disease conditions such as viral arthritis (VA), tenosynovitis and Malabsorption Syndrome (MAS). They are also isolated from chickens without any clinical signs [35]. Although the relationship between reovirus and tenosynovitis has been established, a causative role is less clear in MAS [36]. The characterization and the classification of ARV might be important for the epidemiology of MAS and VA for the choice of the appropriate vaccine in farms with ARV problems. Although ARV infections still cause problems in poultry, the only available ARV sequences are for strains from the USA,
Canada, Taiwan, Australia, the Netherlands, Germany, Japan, England and China. Recently, $\sigma \mathrm{C}$ encoded gene sequences from Indian isolates became available in Genbank [7,8] (Table 2).

Genotyping of ARV using $\sigma \mathrm{C}$ encoded gene revealed at least 6 different genotypes [27], but correlations between genotypes, pathogenic characteristics and serotype classification have not been well established yet. A phylogenic study using the $\sigma \mathrm{C}$ encoded gene indicated that, despite the close relationship with the first USA isolates belonging to clusters I and II, those recently isolated from chickens with Runting-Stuning Syndrome (RSS) showed dispersion and were classified in the 3 different clusters III, IV and VI

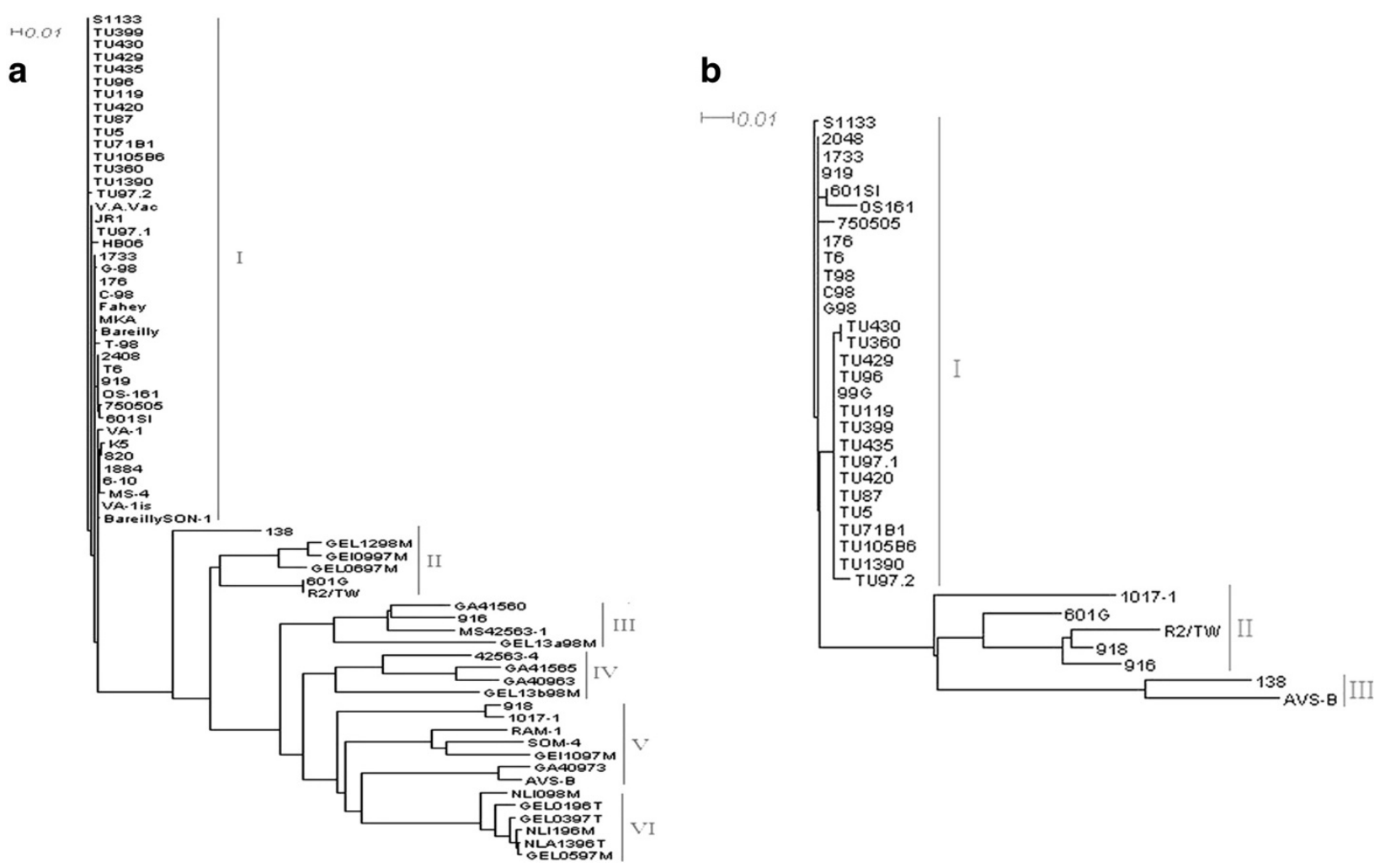

Figure 2 Phylogenic trees of the $\sigma C(a)$ and part of the $\sigma B(b)$ genes of Tunisian ARV strains. The trees were generated on the base of nucleotides sequences using splits tree phylogenic software (version 4.10) with distance-based neighbour-joining ( $\mathrm{NJ}$ ). The reliability of the trees was assessed by bootstrap analysis with 1.000 replications; only bootstrap values of $>90 \%$ are shown. The length of the horizontal lines is proportional to the minimum number of nucleotide differences required to join nodes. The vertical lines are spacing branches and labels. The scale bar is proportional to the phylogenic distance (Table 2). 
(Table 2, Figure 2b). They remain quite different from Australian and Dutch strains, classified in the clusters V and VI, respectively. The first strains isolated from Taiwan were classified in cluster I, whereas the more recent ones were dispersed between the 3 clusters II, III, and V. Furthermore, the German strains isolated during the last two years are much more dispersed and classified into 5 clusters. Finally, the trypsin-resistant strain JR1 is classified in the cluster I $[8,27,33]$.

Molecular characterization of the $\sigma \mathrm{C}$ sequences of all Tunisian ARV, isolated from different field conditions over a twelve years period and compared to several published strains, allowed their classification in one cluster. However, no correlation could be established between the $\sigma \mathrm{C}$ gene sequences and the disease conditions in the field. ARV were also isolated from apparently healthy chickens, making their classification in a true lineage difficult as stated by Kant et al. [7].

The $\sigma \mathrm{C}$-encoding gene has evolved into six clusters, while the other S-class genes have diverged into two to four clusters [27]. It displayed features of the highest level of sequence divergence and rapid evolution. Therefore, this gene could be used as a genetic marker for the classification of ARV isolates [27,28]. Such classification in clusters is independent of determination of the $5^{\prime}$ end, the 3 ' end or the whole ORF of the $\sigma \mathrm{C}$ gene. Furthermore, sequencing of a representative part of this gene seems to be sufficient [7].

The major part of $\sigma \mathrm{C}$ gene sequences of the Tunisian isolates was closely related to the very well-known American strain S1133. Only nucleotide sequences of the 97.1 and 97.2 strains showed mutations at the positions 354 and 355, respectively. A relationship between the 97.1 and JR1 strains is possible; however, data about the $\sigma \mathrm{B}$ gene sequence of the later is not yet published for a possible gene comparison.

Analyses of the whole $\sigma \mathrm{B}$-encoding gene were performed to allow rapid detection of ARV infections with different Tunisian isolates. The constructed Phylogenic trees showed in previous studies that the gene evolves into 2-3 lineages $[8,27]$. Analyses of the published sequences demonstrated that it evolves into 3 clusters, results obtained when using sequences of the whole gene or the representative sequence used in our work. Recently, we performed a restriction fragment length polymorphism (RFLP) with two restriction enzymes that cut in two sites among those containing mutations on our amplicons (data no shown). PCR/RFLP can be a procedure used for rapid characterization and differentiation of Tunisian ARV isolates.

Mutations do exist in the $\sigma \mathrm{B}$ gene sequences of Tunisian strains, allowing their classification into 4 groups: a first group containing the TU430 and TU360 isolates; a second one with the TU429, TU96 and TU119 isolates; a third group containing the TU339, TU87, TU5, TU420, TU105B6, TU1390, TU71B1, TU435 and TU97.1 isolates and the fourth group with only the TU97.2 isolate. The substitution at position 467 was observed for all ARV with respect to the S1133 strain.

Sigma B protein was described as a high variable protein and possesses group-specific neutralizing epitopes [37]. Alignment analysis of amino acids of part of the $\sigma B$ protein showed that only the substitution at position 171 is silent, whereas all other mutations at positions $308,438,467,521$ and 656 are non-synonymous and induced substitution of the corresponding translated AA (Figure 1b). These mutations were also observed for the Chinese isolate $99 \mathrm{G}$ and indicated a possible relationship between the Tunisian and the Chinese ARVs. Unfortunately, the $\sigma \mathrm{C}$ gene sequence of the $99 \mathrm{G}$ isolate is not available for comparison. For the Taiwanese strains, the majority of nucleotide substitutions were silent because they occur at the third position of the codons [27].

The $\sigma \mathrm{C}$ protein, located on the surface of the outer layer capsid, induces neutralizing antibody production and is the determinant for ARV serotypes [16]. In previous studies, ARV strains were differentiated by virus neutralization assays [38]. Serological classification of ARV strains has not been successful because of high cross-reactivity of the neutralizing antibodies [33]. Nowadays, genotypic classification of ARV strains is performed using RT-PCR in combination with phylogenic analysis or other molecular techniques, such as RFLP $[7,26]$. All phylogenic studies have classified ARV isolates into various groups and lineages; however, metaanalytically, there were no identical patterns. Such results suggested that different ARV genome segments may evolve in independent manner [27]. It is puzzling that no correlation was found between genotypes, serotypes and pathotypes, given detectable genetic differences of different ARV strains [7]. Divergences between genotypes, serotypes and pathogenicity suggested the involvement of multiple genes and proteins in serologic and pathogenic determination [33]. It may also result from high mutation rate of viral RNA and the possible reassortment between 2 strains co-infecting the same host [27,39]. Geographic characteristic conditions could facilitate exchanges between segmented genomes within small numbers of viral strains, which would result in less genetic variation within a region [33].

Vaccination against reovirus infections generally involves a live S1133 vaccine followed by an inactivated vaccine containing strains 1733 and/or 2408, knowing to be related to tenosynovitis and stunting syndrome pathologic conditions and belonging to the same subtype [40,41]. Although chickens were vaccinated, ARV pathogens still persist in Tunisian poultry. Serotyping studies are therefore needed to further elucidate the antigenic 
characteristics of these isolates and adapt the vaccination program.

\section{Conclusion}

In the present study, we characterize genetically avian reovirus Tunisian strains isolated from commercial chickens reared in different geographic areas, during a 12 year period. The classification of ARV could be realized using the $\sigma \mathrm{C}$ gene, the most variable known gene but other gene studies may provide additional information. It was not possible, however, to correlate the genotype of isolated strains with neither a specific pathologic conditions nor a geographic or temporal parameter. Although the vaccination against ARV is used in farms, the pathogens still persist in Tunisian poultry flocks. Serotyping studies are underway to characterize the antigenic proprieties of these isolates, which will help adapting the vaccination program.

\section{Abbreviations}

AA: Amino acid; ARV: Avian reoviruses; SPF: Specific pathogen free: CEF: Chicken embryo fibroblast; CELC: Chicken embryo liver cells; CPE: Cytopathic effect; ARV: Avian reovirus; RT: Reverse transcription; N-PCR: Nested PCR; RSS: Runting-Stuning Syndrome; MAS: Malabsorption Syndrome; RFLP: Restriction fragment length polymorphism.

\section{Competing interests}

The authors declare that they have no competing interests.

\section{Authors' contributions}

HKY is a PhD student, who carried out the avian reovirus genes detection by RT-PCR, was involved in sequencing and phylogenic studies and drafted the manuscript. $\mathrm{BH}$ and $\mathrm{GL}$ helped with experimental procedures and manuscript preparation. SAD reviewed the manuscript critically for important intellectual content. GA conceptualized the study, was involved in design of the trials, supervised all facets of the research and assisted in the writing process. All authors have red and approved the final manuscript.

\section{Acknowledgement}

This work was fully supported by a grant from the Tunisian Ministry of Higher Education and Scientific Research (Project LRO0SP07).

\section{Author details}

'Laboratory of Epidemiology and Veterinary Microbiology, Institut Pasteur de Tunis, University of Tunis - El Manar, 13 place Pasteur, BP 74, 1002, Tunis-Belvedere, Tunisia. ${ }^{2}$ Unité de Régulation des Infections Rétrovirales, Institut Pasteur, 27 Rue Dr. Roux, 75724, Paris, France.

Received: 5 March 2012 Accepted: 10 December 2012 Published: 5 January 2013

\section{References}

1. Ni Y, Kemp MC: A comparative study of avian reovirus pathogenicity: virus spread and replication and induction of lesions. Avian Dis 1994, 39:554-566.

2. Xie Z, Fadl AA, Girshick T, Khan MI: Amplification of avian reovirus RNA using the reverse transcriptase-polymerase chain reaction. Avian Dis 1997, 41:654-660.

3. Van de Zande S, Kuhn EM: Central nervous system signs in chickens caused by a new avian reovirus strain: a pathogenesis study. Vet Microbiol 2007, 120:42-49.

4. Shapouri MRS, Kane M, Letarte M, Bergeron J, Arella M, Silim A: Cloning, sequencing and expression of the S1 gene of avian reovirus. J Gen Virol 1995, 76:1515-1520.
5. Liu HJ, Giambrone JJ: Molecular characterization of avian reoviruses using nested PCR and nucleotide sequence analysis. J Virol Methods 1997, 65:159-167.

6. Liu HJ, Giambrone JJ, Nielsen BL: Amplification, Cloning and Sequencing of the $\sigma \mathrm{C}$-encoded gene of avian reovirus. J Virol Methods 1997, 63:203-208.

7. Kant A, Blak F, Born L: Classification of Dutch and German avian reoviruses by sequencing the $\sigma$ C proteins. Vet Res 2003, 34:203-212.

8. Banyai K, Dandar E, Dorsey KM, Mato T, Palya V: The genomic constellation of a novel avian orthoreovirus strain associated with runting-stunting syndrome in broilers. Virus Genes 2011, 42:82-89.

9. Spandidos DA, Graham AF: Physical and chemical characterization of an avian reovirus. J Virol 1976, 19:968-976.

10. Varela R, Benavente J: Protein coding assignment of avian reovirus strain S1133. J Virol 1994, 68:6775-6777.

11. Bodelon G, Labrada L, Martinez-Costas J: Modification of late membrane permeability in avian reovirus infected cells. J Biol Chem 2002, 277:17789-17796.

12. Salsman J, Top D, Boutilier J, Duncan R: Extensive syncytium formation mediated by the reovirus FAST proteins triggers apoptosis-induced membrane instability. J Virol 2005, 79:8090-8100.

13. Liu HJ, Lin PY, Wang LR, Hsu HY, Liao MH, Shih WL: Activation of small GTPases RhoA and Rac1 is required for avian reovirus p10-induced syncytium formation. Mol Cells 2008, 26:396-403.

14. Liu HJ, Lin PY, Lee JW, Hsu HY, Shih WL: Retardation of cell growth by avian reovirus p17 through the activation of p53 pathway. BBRC 2005, 336:709-715.

15. Chulu JLC, Huang WR, Wang L, Shih WL, Liu HJ: Avian reovirus nonstructural protein p17-induced G2/M cell cycle arrest and host cellular protein translation shutoff involve activation of p53-dependent pathways. J Virol 2010, 84:7683-7694.

16. Martinez-Costas J, Grande A, Varela R, Garcia-Martinez C, Benavente J: Protein architecture of avian reovirus $\mathrm{S} 1133$ and identification of cell attachment protein. J Virol 1997, 71:59-64.

17. Shih WL, Hsu WH, Liao MH, Lee LH, Liu HJ: Avian reovirus $\sigma \mathrm{C}$ protein induces apoptosis in cultured cells. Virology 2004, 32:65-77.

18. Huang WR, Wang YC, Chi PI, Wang CY, Lin CH, Liu HJ: Cell entry of avian reovirus follows a caveolin-1-mediated and dynamin-2-dependent endocytic pathway that requires activation of p38 mitogen-activated protein kinase (MAPK) and Src signalling pathways as well as microtubules and small GTPase Rab5 protein. J Biol Chem 2011, 286:30780-30794.

19. Yin HS, Shieh HK, Lee LH: Characterization of the double stranded RNA genome segment S3 of avian reovirus. J Virol Methods 1997, 67:93-101.

20. Yang ZJ, Wang CY, Lee LH, Chuang KP, Lien YY, Yin HS, Tong DW, Xu XG, Liu HJ: Development of ELISA kits for antibodies against avian reovirus using the sigmaC and sigmaB proteins expressed in the methyltropic yeast Pichia pastoris. J Virol Methods 2010, 163:169-174.

21. Martinez-Costas J, Gonzalez-Lopez C, Vakharia VN, Benavente J: Possible involvement of the double-stranded RNA-Biding core protein $\sigma \mathrm{A}$ in the resistance of avian reovirus to interferon. J Virol 2000, 74:1124-1131.

22. Chiu CJ, Lee LH: Cloning and nucleotide sequencing of the $\mathrm{S} 4$ genome segment of avian reovirus S1133. Arch Virol 1997, 142:2515-2520.

23. Huang PH, Li YJ, Su YP, Lee LH, Liu HJ: Epitope mapping and functional analysis of sigma A and sigma NS proteins of avian reovirus. Virology 2005, 332:584-595.

24. Kibenge FSB, Wilcox GE: Tenosynovitis in chickens. Vet Bull 1983, 53:431-443.

25. Lin YH, Lee LH, Shih WL, Hu YC, Liu HJ: Baculovirus surface display of sigma $\mathrm{C}$ and sigma $\mathrm{B}$ proteins of avian reovirus and immunogenicity of the displayed proteins in a mouse model. Vaccine 2008, 26:6361-6367.

26. Lee $\mathrm{LH}$, Shien JH, Shien HK: Detection of avian reovirus RNA and comparison of a portion of genome segment $\mathrm{S} 3$ by polymerase chain reaction and restriction enzyme fragment length polymorphism. Res Vet Sci 1998, 65:11-16.

27. Liu HJ, Lee LH, Hsu HW, Kio LC, Liao MH: Molecular evolution of avian reovirus: evidence for genetic diversity and reassortment of S-class genome segments and multiple cocirculating lineages. Virology 2003, 314:336-349.

28. Liu HJ, Lee LH, Shih WL, Li YJ, Su HY: Rapid characterization of avian reoviruses using phylogenetic analysis, reverse transcription-polymerase chain reaction and restriction enzyme fragment length polymorphism. Avian Pathol 2004, 33:171-180. 
29. Hall TA: Bioedit: a user-friendly biological sequence alignment editor and analysis program for windows 95/98/NT. Nucl Acids Symp Ser 1999, 41:95-98.

30. Bourogâa H, Miled K, Gribâa L, El Behi I, Ghram A: Characterization of new variants of avian infectious bronchitis virus in Tunisia. Avian Dis 2009, 53:426-433.

31. Shmulevitz M, Yameen Z, Dawe S, Shou J, OHara D, Holmes I, Duncan R: Sequential partially overlapping gene arrangement in the Tricistronic S1 genome segments of avian reovirus and Nelson Bay reovirus: Implications for Translation Initiation. J Virol 2002, 76:609-618.

32. Zhang Y, Liu M, Shuidong O, Hu QL, Guo DC, Chen HY, Han Z: Detection and identification of avian, duck, and goose reoviruses by RT-PCR: goose and duck reoviruses are part of the same genogroup in the genus Orthoreovirus. Arch Virol 2006, 15:1525-1538.

33. Guo K, Dormitoria T, Ou SC, Giambrone J: Detection and differentiation of avian reovirus using SYBR-green I-based two-step real-time reverse transcription PCR with melting curve analysis. Avian Dis 2012, 56:369-376.

34. Huson DH, Bryant D: Application of phylogenetic networks in evolutionary studies. Mol Biol Evol 2006, 23:254-267.

35. Robertson MD, Wilcox GE: Avian reovirus. Vet Bull 1986, 56:155-174

36. Van der Heide L: Viral arthritis/Tenosynovitis. Avian Pathol 1977, 6:71-84.

37. Wickramasinghe R, Meanger J, Enriquez CE, Wilcox GE: Avian reovirus proteins associated with neutralization of the virus infectivity. Virology 1993, 194:688-696.

38. Wood GW, Nicholas RAJ, Hebert CN, Thornton DH: Serological comparisons of avian reoviruses. J Comp Pathol 1980, 90:29-38.

39. Rekik MR, Silim A, Bernier G: Serological and pathogenic characterization of avian reoviruses isolated in Quebec. Avian Pathol 1991, 20:607-617.

40. Van der Heide L, Kalbac M, Brustolon M: Development of an attenuated apathogenic reovirus vaccine against viral arthritis/tenosynovitis. Avian Dis 1983, 27:698-706.

41. Giambrone JJ, Solano W: Serologic comparison of avian reovirus isolates using Virus Neutralization and an Enzyme-Linked Immunosorbent Assay. Avian Dis 1988, 6:678-680.

\section{Submit your next manuscript to BioMed Central and take full advantage of:}

- Convenient online submission

- Thorough peer review

- No space constraints or color figure charges

- Immediate publication on acceptance

- Inclusion in PubMed, CAS, Scopus and Google Scholar

- Research which is freely available for redistribution 